\title{
Clergy Perceptions of Denominational, Doctrine and Seminary School Support for Health and Wellness in Churches
}

\author{
Melissa Bopp ${ }^{1}$, Benjamin Webb ${ }^{1}$, Meghan Baruth ${ }^{2} \&$ Jane A. Peterson ${ }^{3}$ \\ ${ }^{1}$ Department of Kinesiology, The Pennsylvania State University, University Park, PA \\ ${ }^{2}$ Department of Health Sciences, Saginaw Valley State University, University Center, MI \\ ${ }^{3}$ College of Nursing, University of Missouri-Kansas City, Kansas City, MO \\ Correspondence: Melissa Bopp, The Pennsylvania State University, Dept Kinesiology, 268R Recreation Building, \\ University Park, PA 16802, USA.
}

Received: November 9, 2013 Accepted: November 20, 2013 Available online: December 11, 2013

doi:10.11114/ijsss.v2i1.274 URL: http://dx.doi.org/10.11114/ijsss.v2i1.274

\begin{abstract}
Background: Churches are a viable community partner for reaching large populations for health promotion interventions. Despite their usefulness, little is known about the institutional capacity or beliefs of churches toward health. The purpose of this qualitative study was to examine how a churches' doctrine, parent organization (e.g. conference/diocese), and leader training (e.g. seminary school) perceive and support health-related issues.

Design \& Methods: Clergy ( $\mathrm{n}=24)$ from multiple denominations participated in a semi-structured interview. The interviewer asked questions about the doctrine/philosophy of their church on health, parent organization support for health, and education and training on health. Interviews were recorded, transcribed and coded.

Results: Clergy reported that stewardship and holistic views on health were a part of their churches' doctrine. Health insurance programs and clergy wellness initiatives were the most common form of health-related support from parent organizations. The majority of clergy reported minimal or no instruction on health during their education/training, and desired instruction on self-care in seminary school. These results indicate there are a number of institutional influences on health and wellness within churches.

Conclusions: Future programs could include policy and environment level initiatives to address clergy health, and the development of culturally tailored intervention concurrent with church doctrine.
\end{abstract}

Keywords: faith-based, community health, organizational change, worksite health

\section{Introduction}

The United States Department of Health and Human Services Healthy People 2020 mission includes engaging multiple sectors throughout the community to promote and maintain health across diverse groups within the population (U.S. Department of Health and Human Services, 2012). Some of the overarching goals of this initiative include the creation of physical and social environments that promote health and related health behaviors, improve quality of life, and healthy development. This focus falls in line with community-level strategies for promoting health from a social ecological framework (McLeroy, Bibeau, Steckler, \& Glanz, 1988), taking into consideration not just individual and interpersonal influences, but also institutional, community, policy, and environmental influences as well. Health promotion researchers and practitioners can reach large populations with health promotion efforts through community level initiatives in order to achieve the greatest effect on public health outcomes. Intervention strategies partnering with community institutions such as schools, worksites, healthcare settings or faith-based organizations (FBOs), have shown to be effective for improving health outcomes, reaching diverse groups, and developing sustainable programs (Task Force on Community Preventive Services, 2005).

In the United States, FBOs reach a substantial portion of the general population as $83 \%$ of individuals in this country report an affiliation with a religious denomination (Pew Research Center, 2008a). This translates into regular attendance at services for much of the population; $39 \%$ report attending religious services one or more 
times a week, and an additional 15\% attending services 1-2 times a month (Pew Research Center, 2008b). FBOs provide a long-standing, trustworthy, physical environment where individuals have an existing social support network, resulting in a setting that is an excellent potential partner for health promotion. In a review of health promotion programs in FBOs, DeHaven et al.(2004) found that the majority of interventions delivered in this setting were effective for improving health or changing behavior, indicating the importance of this setting for achieving the public health goals set forth in Healthy People 2020.

Developing a culturally tailored health promotion intervention will increase the likelihood of success for improving health and changing health behaviors (Kreuter, Lukwago, Bucholtz, Clark, \& Sanders-Thompson, 2003), and within FBOs that involves considering spiritual tailoring, being respectful of FBO traditions, missions, leadership and hierarchy. Based on the many faith-based interventions that have been delivered, expert recommendations have indicated some of the most important influences on the success of interventions. Reviews of successful strategies for faith-based health promotion by Campbell et al. (2007), Demark-Wahnefried et al. (2000)and Peterson el al. (2002) suggest that development of a strong partnership with the FBO as well as the FBO's parent organization (e.g. convention, conference, diocese) is the foundation for building effective health promotion programs. This indicates the importance of understanding not only the dynamics of individual FBOs that may be implementing programs, but also how the FBO interacts within its own denominational hierarchy. Parent organizations within religious denominations vary tremendously in their structure and involvement; some are very formal and provide a business-like framework to organize the network of churches based on a shared financial system (clergy are paid employees of the parent organization) while other denominations have churches united under a parent organization moreso as a shared philosophy and doctrine and the churches have much more autonomy (clergy are employees of the individual churches) (Cross, 2005). Webb and colleagues(2013) found that although there were some differences by denomination/parent organization, it was apparent that even clergy within the same denomination/parent organizationhad varied perceptions of health promotion in FBOs. This further highlights the importance of formative research to understand the influence of denominations/parent organizations on church doctrine and policies regarding health-related issues.

In addition to the importance of the institution, the role of the faith leader in health promotion initiatives is well documented. For many interventions, having the support or endorsement of the pastor dictates FBO-level buy-in, assists with recruitment, and helps to build trust among the FBO members(Campbell et al., 2007; Demark-Wahnefried et al., 2000; Peterson et al., 2002). Like other formal leaders in community settings (e.g. managers in worksites, teachers in schools), faith leaders have a significant influence on the FBO's physical environment and setting level policies, as well as the social environment and the behavioral and social norms within the FBO. Bopp and colleagues (2011) found that the health and health behaviors of faith leaders are strongly related to the health promotion environment of FBOs. Faith leaders with more instruction or education on health and wellness in seminary or formal training had more health promotion programs at their FBO. Recent research has examined the health and wellness environment of seminary schools and has found limited support for health and wellness programming (Bopp \& Baruth, in press). Some seminary schools provide training to future clergy within a particular denomination while other schools serve multiple denominations(Association of Theological Schools, 2007), therein it is essential to examine clerical training in addition to denominational support. This evidence suggests that some of the institutional aspects (e.g. policy, leadership, training opportunities, FBO environment) of the FBO are essential for health promotion.

Although there is evidence to suggest that institutional factors are an important influence on setting-based health initiatives, the extent to which this applies in FBOs is unknown. Therefore, the main research question addressed with this qualitative study was to examine how the churches' doctrine, parent organization, and leader training (e.g. seminary school) are perceived and support health-related issues.

\section{Methods}

\subsection{Participants \& Recruitment}

Local FBOs in the Centre County, PA and Kansas City, MO regions were contacted via letter or email, on regional faith-based email listservs and newsletters, inviting the primary faith leader to take part in a one-on-one interview about faith leaders' perceptions, attitudes, beliefs and experiences with health and included contact information to follow up if they were interested in participating. Although the recruitment materials did not indicate that we were looking for only Christian clergy, all of the participants who volunteers were the lead pastor/clergy member/faith leader at their Christian institution. This study was approved by the institutional review board at Pennsylvania State University. 


\subsection{Procedure}

All interviews were conducted by a trained interviewer at a location of the participant's choosing (e.g. home, FBO, on campus) or on the phone. After providing consent, clergy were asked to complete a brief demographic questionnaire asking about them (age, sex, race/ethnicity, health, education, height, weight, length of service to current church) and their FBO (denomination, size, racial/ethnic diversity of the congregation). The interviewer followed a structured guide and all interviews were recorded and transcribed verbatim. The interviewers were Christian, and trained in the area of qualitative data collection and had moderate to high levels of education on health and wellness. The interviews, which took place between October 2010 and May 2012, lasted approximately 60 minutes and participants were provided with a small incentive ( $\$ 20$ gift card) for their participation.

The interview guide was based on the Social Ecological Model (McLeroy et al., 1988) and included individual, institutional and policy level influences on health and health promotion programming within the church. The questions were developed to expand on the current literature examining how the clergy member, their health and institutional support can influence health and wellness promotion in FBOs (Bopp \& Fallon, 2011; Campbell et al., 2007; Peterson et al., 2002). Participants were asked the following questions (note prompts are not listed):

1. Thinking about the doctrine or philosophy of your church, what are some of the main teachings on health?

2. Thinking about your parent organization (e.g. conference or diocese), describe the activities or support they provide for health and wellness related activities (could include any type of health related activitye.g. blood drives, education, screenings, group based activities).

3. As an employee of your parent organization, describe, if any support they provide specifically for your health and wellness.

4. When you attended school to become a faith leader, what kind of emphasis was there on health and wellness? Developing programs for health and wellness?

5. What kinds of training or instruction would have been appropriate or helpful during your seminary school/other education for preparing you for delivering information or programs about health?

\subsection{Data Analysis}

The interview text was entered into NVivo 8.0 (QSR International PTY Ltd.), a software program that facilitates qualitative data analysis by allowing for the coding and organization of data across themes and interviews. A coding guide developed by the investigators was organized by the social ecological model (McLeroy et al., 1988) and captured the physical and social environmental influences on health promotion in FBOs. Themes were determined after reading the transcripts and consistent issues were identified and discussed by the authors. After in-depth discussion of the codes for each of the transcriptions, practice coding sessions and coding modifications were independently conducted by two of the three coders (the authors). Themes were identified and described with illustrative quotations.

\section{Results}

The demographics of the sample are found in Table 1. Primarily the clergy members $(n=24)$ were male $(n=19$, $79.2 \%)$, White $(\mathrm{n}=16,66.6 \%)$ and middle aged $54.8 \pm 6.5$. Participants had been serving as a primary faith leader for 7.57 \pm 7.47 years. The majority of the pastors served medium (100-500 members) ( $n=13,54.2 \%)$ congregations. The most common affiliations were United Methodist $(n=6,25 \%)$, African Methodist Episcopal (AME) $(n=4,16.7 \%)$, and Baptist $(n=3,12.5 \%)$ denominations. The majority of the pastors self-reported being overweight $(n=8,33.3 \%)$ or obese $(n=10,41.7 \%)$, while, of the pastors interviewed $45.8 \%$ self-reported meeting current physical activity recommendations and $50.0 \%$ reported eating 5 or more fruits and vegetables daily. The data for each question were coded by theme and the most common themes for each category (church doctrine, parent organization, and seminary school) are noted below.

Table 1. Demographics of the Sample $(n=24)$

\begin{tabular}{lcc}
\hline Characteristic & Mean (SD) & $\mathrm{N}(\%)$ \\
\hline Age (range 34-68 years) & $54.8(6.5)$ & \\
$\%$ Male & & $19(79.2)$ \\
Race, & & \\
\hline
\end{tabular}


\% White $16(66.7)$

\begin{tabular}{lc} 
\% African American & $8(33.3)$ \\
\hline \% reporting very good/excellent health & $14(58.3)$ \\
\hline Body Mass Index categories & $6(25.0)$ \\
Normal $\left(19-24.9 \mathrm{~kg} / \mathrm{m}^{2}\right)$ & $8(33.3)$ \\
Overweight $\left(25-29.9 \mathrm{~kg} / \mathrm{m}^{2}\right)$ & $10(41.7)$ \\
Obese (greater than $\left.30 \mathrm{~kg} / \mathrm{m}^{2}\right)$ & $12(50.0)$ \\
\hline meeting current fruit and vegetable recommendations & $11(45.8)$ \\
\hline$\%$ meeting current physical activity recommendations & \\
\hline Denomination & $6(25.0)$ \\
Methodist & $4(16.7)$ \\
African Methodist Episcopalian & $3(12.5)$ \\
Baptist & $2(8.3)$ \\
Lutheran & $2(8.3)$ \\
United Church of Christ & $2(8.3)$ \\
Non-denominational & $1(4.2)$ \\
Episcopal & $1(4.2)$ \\
Church of Christ & $1(4.2)$ \\
Evangelical & $1(4.2)$ \\
Unitarian Universalist & \\
\hline Church Size & $6.57(7.47)$ \\
Small & $25(25.0)$ \\
Medium & $13(54.2)$ \\
Large & $2(12.3)$ \\
Extra Large & \\
\hline Number of years serving congregation (range $1-23$ years) & \\
\hline & \\
\hline
\end{tabular}

\subsection{Church Doctrine or Philosophy}

Clergy cited a number of themes describing their church's doctrine or philosophy on health, which can be found in Table 2 with illustrative quotations. Several $(n=10)$ cited stewardship as being a part of their doctrine, indicating that taking care of one's body (or "temple") as an important part of their faith. One White male Lutheran leader stated: "It [health] would probably fall under the banner of stewardship personal stewardship that we are what we have and who we are is not ours. Our bodies are on loan [and] they have to be returned to the one who made them and gave them to us so there there's an accountability factor." A White female United Church of Christ leader indicated that stewardship included thinking of others as well, stating: "We talk more about caring for others in need than we talk about taking care of ourselves. And the mission statement of the church and sermon messages in how we take care of one another - and I encourage everyone to be a community of faith and a church family [more] than some of the others [pastors]. It's really more about taking care of one another or taking care of others." Other stewardship themes that were mentioned included: helping others to become good stewards $(n=2)$, being accountable to God and others for one's health $(n=1)$, and being a good role model $(n=1)$. Several $(n=8)$ leaders indicated that their doctrine included a philosophy of holistic health. One White male Methodist leader indicated the depth of this connection, stating: "from the founding principles, the faith - the Christian faith - is very holistic- of body, mind, and soul. Those are integrated in a very significant way, biblically and theologically and practically in American Methodism." A few clergy offered reference to the Bible, scripture or specific denomination as it pertains to health. Five leaders indicated that verses from Corinthians (1 Cor. 3:16-17, 6:19-20 New International Version) were relevant to health, reinforcing the idea of the body as a "temple" to be cared for and respected. Three Methodist leaders referred to the founder of their 
denomination as being interested in health, and one indicated that "John Wesley, who is the founder of Methodism, spoke a lot about the importance of keeping healthy." Two leaders, one Methodist and one Episcopal, referred to the aforementioned passages in the Bible referring to the "body as a temple to indicate that individuals should refrain from unhealthy habits, specifically smoking and drinking alcohol".

Table 2. Illustrative quotes for Church/Denomination Doctrine and Health

\begin{tabular}{ll}
\hline Theme & Quote \\
\hline Stewardship & "There's kind of a long-standing, broadly accepted belief that God considers our body to be our \\
& temple and that, as temporary stewards of an earthly body, it's up to us to be good custodians \\
& of it. And that generally means having a healthy lifestyle" - White, Male Church of Christ \\
leader
\end{tabular}

"I believe we are now beginning to reclaim that responsibility and to hold one another accountable to say that you've got to watch your health because the other thing that it impacts, too. Not only does it impact your personal health but it impacts the medical insurance that we pay and the more medical insurance we pay then decreases the amount of money that we have to do ministries and to reach out to other people. So we're trying to enlighten and help people understand that their own personal health means more than something just to them. It has over-arching effects on the world."- White, Male Methodist leader

"Well mainly that health, and that we need to have a healthy church, amen. Because if you're not healthy you can't help others and you can't do ministry or engage in ministry if you're not healthy."- African American, Female AME leader

"that's what we teach is we have - God created matter, and it matters. And it's not just, "Oh, we're waiting to bide our time to get to heaven," because one day we'll be resurrected again into perishable bodies, flesh and blood. So we need to honor that while we're here."- White, Male Church of Christ leader

Holistic "So that's the doctrine that we hold to New Testament teaching on - again, not the heresy of approach the early 200s of dualism but that the incarnation Jesus in the flesh is how we need to look at our lives. Flesh and spirit together make that living being person."-White, Male Church of Christ leader

"because Christianity is so much more based in Hebrew thought - the early Christian writers of the Bible came from a Hebrew background, and the Hebrew thought and philosophy and culture was much more holistic. It didn't have this dichotomy between physical/bad, spiritual/good at all."- White, Male Baptist leader

"There has been a move in the past 20 years or so to see a closer correlation between spirituality on the one hand and physical well-being on the other, and those two concerns were taken apart, probably most notoriously by Thomas Aquinas a long time ago."- White, Male Episcopal leader

\begin{tabular}{ll}
\hline $\begin{array}{l}\text { As a role } \\
\text { model }\end{array}$ & "It would probably fall under the banner of stewardship personal stewardship that we are what \\
& we have and who we are is not ours our bodies are on loan that have to be returned to the one \\
who made them and gave them to us so there there's an accountability factor. Beyond that \\
there's also the stewardship of life quality of life in terms of our relationships. Personally you \\
know in family and in the greater community become a concern. For followers of Jesus who \\
don't maintain their health become poor examples for the rest of the world. What is Christianity \\
all about if you know you're allowing yourself to go to pot. So that becomes that's all part of \\
our overall doctrine" - White, Male Lutheran leader
\end{tabular}

"There are some who believe very strongly that people who say they are Christians should 
abstain from certain behaviors like smoking or drinking across the Episcopal Church. Those are concerns, but they're not driving concerns or overriding concerns." - White, Male Episcopal leader

"There are scriptures that talk about the body as a temple and though that's the one scripture that I always hang everything as part - as our wellness point. But the body as a temple it's as if a sacrifice holy and acceptable. Well, you can't have a holy and acceptable temple if you are putting everything that's not good for it in it. So, that's one that I use that works well and covers all of the health care and health concerns."- African American, Male AME leader

\subsection{Parent Organization Support for Health and Wellness}

There were three clergy members (Church of Christ, Non-denominational, and Baptist) who indicated they did not really have a parent organization that offered support, programming or initiatives for health. Several clergy indicated that their parent organization offered poor $(n=2)$ or no support at all $(n=3)$ for health-related programming. A number of clergy however, indicated that they felt their parent organization offered some degree of support for health including: denominational supported healthcare facilities $(n=1)$, establishing health and wellness committees $(n=2)$, organizing parish nursing programs $(n=3)$, and delivering educational programs $(\mathrm{n}=5)$.

The most common finding for parent organizational support was related to health insurance policies (often offered through the parent organization) or clergy wellness programs linked to health insurance. In some parent organizations the clergy are employees of the organization rather than of the individual churches, therein clergy health is also an employee health concern. Thirteen leaders indicated that their denominational parent organization offered some form of health insurance with wellness incentives or programs included, such as educational programs, insurance incentives, weight loss, stress management, and physical activity promotion. One White male Methodist leader indicated "The United Methodist judicatories in the United States are well-rooted in providing assets, for example, for clergy and laity: health insurance, counseling referral services, cash for crisis interventions, support systems of all kinds." A White female United Church of Christ leader emphasized the wellness initiatives linked to their health insurance, "Part of the United Church of Christ insurance is some workshops on your own health and taking care of yourself. They do webinars occasionally around some of those issues to help you be aware. They're very aware of clergy being overweight. Their newsletter often talks about that, and these are some tips and suggestions and ways to be aware of that more than anything else. The healthcare, itself that we have has a lot of wellness pieces in that, getting your checkups and making sure your medications are affordable and those kind of things, so we can really take care of ourselves." One AME female leader noted that "At our national congress our educational portion they do have different classes at our national convention they have healthcare, health screening, and many of the pharmaceutical companies and whatnot will come." Most $(\mathrm{n}=6)$ of the African American clergy reported that they did not have benefits provided by the parent organization when applicable. Most African American clergy when referring to their denominational structure, stated that their compensation was paid by the local churches and budgets were limited for health benefits

Three leaders noted the importance of current policies to help relieve stress and improve mental health, put in place either by the parent organization or their individual church governing board. For example, a White male Baptist leader explained:

We try to be pretty generous just in terms of saying to people, "if you need a mental health day - if you just need some time away, you need to lead yourself." So we're going to give you a pretty good amount of flexibility. You still need to get your job done, but if you're saying, "Hey, I can do what I need to do this week in four days and I'm going to take two days away to just spend some time in solitude and recharge and whatever," that's all stuff that we're very flexible with.

\subsection{Seminary School Support for Health and Wellness}

The themes noted for seminary school support for health and wellness are displayed in Table 3 with illustrative quotes. The majority of clergy $(n=16)$ indicated that health and wellness education was minimally or not at all during seminary school. Three faith leaders indicated there were physical activity programs available to the seminary students and other leaders $(n=3)$ mentioned other types of programs related to student health .The leaders reported that health and wellness related content was covered in varying depths at seminary school, 
ranging from minimal coverage as part of their coursework, to extensive. Specifically, one White male Methodist leader noted that health and wellness had become institutionalized at the school, stating

The General Board of Pensions oversaw development for health programming at the seminary and came and made the seminary a model for the other United Methodist seminaries in the U.S. to talk about integrating theological education and wellness education into the mainstream curriculum.

Table 3. Illustrative Quotes for Seminary School Influence on Health and Wellness

\begin{tabular}{ll}
\hline Theme & Quotations \\
\hline $\begin{array}{l}\text { Health } \\
\text { programs } \\
\text { available }\end{array}$ & $\begin{array}{l}\text { "It's more of an individual thing where they[seminary school] offer - they provide to you } \\
\text { spiritual counselors and provide to you different opportunities that are happening with physical } \\
\text { well-being - what is around there. They make memberships available to the local YWCA so } \\
\text { that they encourage people to take part in those type of things."- White, Female ECLA leader }\end{array}$ \\
\hline $\begin{array}{l}\text { Health } \\
\text { covered in } \\
\text { seminary }\end{array}$ & $\begin{array}{l}\text { "Parish health care was brought up as part of a course called Theory and Practice of Ministry. } \\
\text { school } \\
\text { probably about a half hour. And again, the purpose of that half hour was to point to the } \\
\text { diocesan resources that are available and the importance of developing parish health programs."- } \\
\text { White, Male Episcopal leader }\end{array}$
\end{tabular}

"I took a class on pastoral care, which was more self-care and self-awareness. I also took a class on working with children in trauma and crisis and how to counsel and work with families that are in crisis, including health crises, how to go into a hospital room and how to work with children. . "- White, Female United Church of Christ leader

Negative “And actually, I didn’t serve a parish while I was going to seminary but a lot of pastors do influence on Methodist pastors do. And I can't imagine how they stay anywhere near sane much less health healthy trying to serve a parish and be students as well because it's just way too much going on."-White, Female Methodist leader

Helpful "I suspect that the better option would have been modeling proper health practices prior to going Programs in to seminary and the seminary itself modeling it in terms of meals that are provided snacks that Seminary are provided"- White, Male Lutheran leader

School

"And so what we teach is stewardship and that includes our bodies that we're to be good stewards of our bodies. And we are given these gifts and to take care of them. And I think if that would have been maybe part of the training, again a holistic approach to stewardship, it's not just money but it's everything you have, your assets, which includes your health." - White, Male Church of Christ leader

"But again, it's that message that maybe they could have counteracted that message with some very good solid teaching on health and wellness. I don't know, again, if it would be in the form of a specific class or just maybe sprinkled throughout other classes and topics that you were doing but just somehow to get the message like, "Hey, take care of your body; take care of your health," because honestly, the things that I read now and study on my own, this is exactly what you hear."- White, Male Church of Christ leader

"If there was a class that was strictly kind of focusing on that[self-care], because if there's no focus you almost forget about it, amen. And to understand that that is a big part of ministry, making people well, amen, and be well. Your congregation has to be healthy, the Pastor has to be healthy. And so, maybe talking about how you put together health ministry."- African American, Female, AME leader

Other things that were mentioned under this theme included a focus in seminary on individual counseling skills $(n=1)$, seminary schools offered continuing education that included health $(n=1)$, and instruction on the importance of self-care $(n=4)$. One White female United Church of Christ leader explained how the seminary emphasized self-care: 
We are encouraged in seminary to be sure that we are doing self-care, which is getting enough sleep, eating well, taking your Sabbath time, your rest time, your day off, so that you have a more balanced life. It's easy for a pastor to do 80,90 hours a week if you're not paying attention, especially during Advent and Lent, very busy church times. But I remember those lessons and those lectures and talking about how important it is.

An African American male Baptist leader stated self-care was well emphasized:

The seminary I attended did an excellent job of making sure that all of us understood the demand of ministry pays a toll on your overall health and that you need to make sure you keep it up as well. Sabbaticals, rest, vacation, things away from the call of the ministry. So yes, it was ingrained through my pastoral care course curriculum.

A few leaders $(n=3)$ noted negative health effects of attending seminary school, linked to poor dietary habits, excessive drinking, and stress or lack of time.

The leaders noted a number of programs or initiatives in seminary school that they felt would have been helpful for them to address health in their congregations. One White male Methodist leader emphasized the importance of making the connection between faith and health and their profession, noting "I think probably one of the most important understandings is taking a look at our health and the effect that it has on our ministry, our ability to do ministry, and those who are around us when we're unhealthy - the idea to think that we can just eat whatever we want or have a lack of exercise and that it only affects me." Two leaders indicated that the interests and behaviors of the seminary faculty and staff made it difficult to focus on health and programs or initiatives to target those would have been helpful.

Six leaders noted that instruction on self-care would have been helpful in seminary school. One African American male AME leader offered an example,

Well I think one thing that I would hope that they would begin to do and don't know if they already do, is to teach young ministers who may want to become pastors - is to teach them that the position is stressful. They need to be prepared for the stress of the position. And it does cause one's time frame to get off health, get off meals, get off - nothing is on a regular routine because you can get called at any time. If they would make them more aware of the demand health wise I think that's the biggest key. I think a lot of times if you are instructed of what's the demand health wise it's going to be - it will be easier for you to start saying well I need to take care of myself, ain't nobody else to tell me; I think I know how to take care of myself. If they did no more than explain the nature of the position and what demands they'll face, I think that would be a great thing.

Seven leaders indicated that having additional coursework on health and theology, counseling for health, or health matters would be helpful for improving their general knowledge and skills. One White male Methodist leader noted however that it was more important for the parent organization to address health issues rather than the seminary school stating

That's [education on health programming] probably more something that should come on the conference level than in my theological studies - is to have some programs or some - to go into more detail as to what is available within the conference because I know there's probably a lot things that are available.

\section{Discussion}

The results of this qualitative study offer a unique insight into some of the institutional issues associated with health promotion in faith-based settings and fill an existing gap in the literature on some of the broad influences on health-related programming beyond the individual church and their leader. This study revealed how clergy perceived links between church level doctrine and health. Additionally, these results indicated an apparent lack of infrastructure for supporting health and health-related programming at the faith-based parent organization and seminary school levels. As a result, there are a number of important implications for future initiatives for creating supportive environments, policies and programs to promote health within faith-based settings.

One of the most consistent themes derived from the interviews highlighted how church doctrine was related to health through stewardship. This is not a surprising finding, given that many spiritually tailored faith-based health promotion interventions have generated messages based on the link between taking care of one's body as being an important part of their faith (Bopp, Peterson, \& Webb, 2012; Campbell et al., 2007; Peterson et al., 2002). The leaders, of multiple denominations, all emphasized this connection, indicating that it could be a relevant and salient theme for promoting health in faith-based settings. The other main theme that evolved out of 
the church doctrine findings suggested that a holistic approach to health, incorporating physical, mental, emotional and spiritual components, was common across multiple denominations. Kreuter et al. (2003) indicated the importance of developing targeted and tailored messages for effective health promotion and cited religiosity is an effective method for influencing positive health behavior patterns, consistent with findings from this study. Stewardship and holistic health appear to be key elements and are applicable for health promotion in faith-based settings.

The findings regarding parent organization support for health were somewhat mixed, from a complete lack of support for health related issues to extensive support for health. Across denominations, the parent organization serves multiple functions, as some are the clergy's employers (e.g. Methodist, Episcopalian) and some simply serve as support for churches and leaders. Cantanzaro and colleagues (2007) found that pastors were more likely to value and offer congregational health ministries if they have adequate support. Combined with our findings, this makes a strong case for organizational level support for health initiatives. Diocesan, conference or regional level educational activities, training opportunities, policies, or funding sources could result in widespread health-related activities within a denomination's churches. Currently existing resources within the parent organization that include health-related content (e.g. regional meetings, websites, mailing lists, continuing education programs) could be used to reach clergy. These results also suggest there is an opportunity for FBOs that are not affiliated with parent organizations to develop and provide their own health and wellness initiatives or partner with other organizations in the community to provide these services. There are several non-profit organizations now available to assist FBOs in delivering programs they are unable or unwilling to offer for themselves. Partnering with these non-profit organizations for health promotion could offer many opportunities for disseminating evidence based strategies to target health behaviors and outcomes (Scheitle, 2010). Further studies should include an investigation of these same research questions from a parent organization perspective.

Health insurance policies and programs were the most common theme raised by clergy when considering the support for health from their parent organization. Similar to many employers, faith-based organizations are most likely concerned with rising healthcare costs among their employees. Healthy People 2020 includes several objectives for worksite wellness programs and other initiatives to promote health and prevent chronic disease and associated healthcare costs (U.S. Department of Health and Human Services, 2012), and the inclusion of policies and programs associated with employee health insurance are a logical approach for faith-based parent organizations to address financial and holistic health.

Other studies have examined health (Proeschold-Bell \& Legrand, 2012), health behaviors (Bopp \& Fallon, 2011), obesity, and chronic disease prevalence among clergy (Proeschold-Bell \& LeGrand, 2010) and found clergy is somewhat unhealthy compared with the general population. Examination of other studies have revealed high rates of clergy burn-out and stress related issues (Bopp, Baruth, Peterson \& Webb, 2013; Weaver, Flannelly, Larson, Stapleton, \& Koenig, 2002), suggesting that the inclusions of policies for mental health, as mentioned by faith leaders in this study, are essential for improving and maintaining all aspects of health. The development of tailored policies to address clergy health, in partnership with health insurance providers, could result in healthier church environments, based on the link shown in other studies that have found that healthier faith leaders are more likely to have more health promotion programs in their own churches (Bopp \& Fallon, 2011). Effective programs could address stress management and incorporate dietary and physical activity routines based on limited schedules and difficult environments (e.g. social expectations for faith leaders associated with eating). Furthermore, other evidence has suggested that engaging in healthy behaviors (i.e. physical activity) is effective for prevention of clergy burn-out and mental health issues (Doolittle, 2010), suggesting the aforementioned connection of mental, physical and spiritual health would be applicable both among church members and church leaders.

The seminary school environment offers an opportunity to provide education to new and early career clergy on the importance of fostering health promotion in their future churches, engaging in healthy lifestyles themselves, and the skills needed for organizing health promotion programs. Several leaders in this study indicated that seminary school was a stressful time and was a negative influence on their health. The need for education on self-care to balance life and health within their profession was also commonly cited by the faith leaders. The leaders also indicated the importance of creating a healthy environment at the seminary school, including policy or environmental changes to improve dietary or physical activity opportunities. Seminary faculty should serve as role models for health, and student-oriented programs to improve the health and health education of seminary students need to be established.

Similar to initiatives to improve health among budding medical professionals in medical school (Estabrook, 2008), reaching clergy in their training programs might help novice clergy focus on health, New clergy are 
beginning to form their ideas about theology, explore connections between the Bible and health, and develop skills as a counselor and church administrator, providing a foundation for health promotion a part of their identity as a faith leader. Previous research has shown that faith leaders receiving more education on health and wellness issues are more likely to have health promotion programs within their churches (Bopp \& Fallon, 2011) suggesting there is a need for culturally relevant education and instruction on issues related to health and wellness during faith leader training. This avenue, with such widespread potential reach, appears to be a logical next step for partnering with faith-based organizations to target population-level health.

Although there were a number of important findings, there were some notable limitations for this study. The first limitation is the possible volunteer bias associated with the study participants; we may have inadvertently recruited individuals that were more interested or aware of health issues. Also, though we reached saturation with our responses, our sample size was small. Perhaps the most significant limitation is our lack of generalizability. The sample was from two specific geographic areas and may not represent other regions of the country. Also, although we had denominational diversity (ten denominations were represented), this is still a limited representation of the hundreds of denominations operating in the United States. Future investigative studies should consider these limitations when attempting to broaden the scope of influence of institutional sources on health promotion.

This study has provided unique insight into the institutional level influences on health and wellness among clergy and FBOs. Our findings address a gap in the literature examining the environment of FBOs and the potential ability to reach broader populations through macro level doctrinal and seminary practical support for physical health promotion by and through clergy. Previous research has primarily focused on the individual FBO, though our results indicate that there is a strong rationale for looking at the "bigger picture" and attempting to understand the breadth and depth of influences on health and wellness programs within faith-based settings. Future studies should build upon these findings to develop objective measures for assessing multiple influences to develop a comprehensive understanding of health promotion efforts in FBOs.

\section{References}

Association of Theological Schools. (2007). Fact Book on Theological Education 2006-2007. Pittsburgh, PA: Association of Theological Schools.

Bopp, M., \& Baruth, M. (in press). Are we Training Healthy Clergy? A description of the health environment of United States Seminary Schools. Journal of Christian Nursing.

Bopp, M., Baruth, M., Peterson, J. A., \& Webb, B. L. (2013). Leading their flocks to health? Clergy health and the role of clergy in faith-based health promotion interventions.Family and Community Health, 36, 182-192. http://dx.doi.org/10.1097/FCH.0b013e31828e671c00003727-201307000-00002 [pii]

Bopp, M., \& Fallon, E. A. (2011). Individual and institutional influences on faith-based health and wellness programming. Health Education Research. 26, 1107-1119. http://dx.doi.org/10.1093/her/cyr096.

Bopp, M., Peterson, J. A., \& Webb, B. L. (2012). A comprehensive review of faith based physical activity interventions. American Journal of Lifestyle Medicine, 6, 460-478. http://dx.doi.org/10.1177/1559827612439285.

Campbell, M. K., Hudson, M. A., Resnicow, K., Blakeney, N., Paxton, A., \& Baskin, M. (2007). Church-based health promotion interventions: evidence and lessons learned. Annual Reviews in Public Health, 28, 213-234. http://dx.doi.org/10.1146/annurev.publhealth.28.021406.144016.

Catanzaro, A. M., Meador, K. G., Koenig, H. G., Kuchibhatla, M., \& Clipp, E. C. (2007). Congregational health ministries: a national study of pastors' views. Public Health Nursing, 24(1), 6-17. http://dx.doi.org/10.1111/j.1525-1446.2006.00602.x.

Cross, F. L. (Ed.). (2005). The Oxford Dictionary of the Christian Church (3rd ed.). New York: Oxford University Press.

DeHaven, M. J., Hunter, I. B., Wilder, L., Walton, J. W., \& Berry, J. (2004). Health programs in faith-based organizations: are they effective? American Journal of Public Health, 94, 1030-1036.

Demark-Wahnefried, W., McClelland, J. W., Jackson, B., Campbell, M. K., Cowan, A., Hoben, K., \& Rimer, B. K. (2000). Partnering with African American churches to achieve better health: lessons learned during the Black Churches United for Better Health 5 a day project. Journal of Cancer Education, 15, 164-167.

Doolittle, B. R. (2010). The impact of behaviors upon burnout among parish-based clergy. Journal of Religion and Health, 49(1), 88-95. http://dx.doi.org/10.1007/s10943-008-9217-7 
Estabrook, K. (2008). Medical student health promotion: the increasing role of medical schools. Acad Psychiatry, 32(1), 65-68. http://dx.doi.org/10.1176/appi.ap.32.1.65.

Kreuter, M. W., Lukwago, S. N., Bucholtz, R. D., Clark, E. M., \& Sanders-Thompson, V. (2003). Achieving cultural appropriateness in health promotion programs: targeted and tailored approaches. Health Education and Behavior, 30, 133-146.

McLeroy, K. R., Bibeau, D., Steckler, A. , \& Glanz, K. (1988). An ecological perspective on health promotion programs. Health Education Quarterly, 15(4), 351-377.

Peterson, J., Atwood, J. R., \& Yates, B. (2002). Key elements for church-based health promotion programs: outcome-based literature review. Public Health Nursing, 19(6), 401-411.

Pew Research Center. (2008a). U.S. Religious Landscape Survey. Religious Affiliation: Diverse and Dynamic. Washington DC: Pew Forum on Religion \& Public Life.

Pew Research Center. (2008b). U.S. Religious Landscape Survey. Religious Beliefs and Practices: Diverse and Politically Relevant. Washington DC: Pew Forum on Religion \& Public Life.

Proeschold-Bell, R. J., \& Legrand, S. (2012). Physical Health Functioning Among United Methodist Clergy. Journal of Religion and Health, 51, 734-42. http://dx.doi.org/10.1007/s10943-010-9372-5

Proeschold-Bell, R. J., \& LeGrand, S. H. (2010). High rates of obesity and chronic disease among United Methodist clergy. Obesity (Silver Spring), 18, 1867-1870. http://dx.doi.org/10.1038/oby.2010.102.

Scheitle, C. P. (2010). Beyond the Congregation: The World of Christian Nonprofits. New York: Oxford University Press.

Task Force on Community Preventive Services. (2005). The Guide to Community Preventive Services. New York: Oxford University Press.

U.S. Department of Health and Human Services (USDHHS). (2012). Healthy People 2020. Retrieved June 20, 2012, from http://www.healthypeople.gov/2020/default.aspx.

Weaver, A. J., Flannelly, K. J., Larson, D. B., Stapleton, C. L., \& Koenig, H. G. (2002). Mental health issues among clergy and other religious professionals: a review of research. Journal of Pastoral Care Counsel, 56, 393-403.

Webb, B., Bopp, M., \& Fallon, E. A. (2013). A Qualitative Study of Faith Leaders' Perceptions of Health and Wellness. Journal of Religion and Health, 52(1), 235-46. http://dx.doi.org/10.1007/s10943-011-9476-6

\section{$($ (c) $)$ EY}

This work is licensed under a Creative Commons Attribution 3.0 License. 